\title{
Effect of colorectal cancer on the number of normal stem cells circulating in peripheral blood
}

\author{
WOJCIECH MARLICZ ${ }^{1}$, KATARZYNA SIELATYCKA ${ }^{2}$, KAROL SERWIN ${ }^{2}$, EWA KUBIS $^{2}$, MARTA TKACZ $^{2}$, \\ RAFAŁ GŁUSZKO ${ }^{1}$, ANDRZEJ BIAŁEK ${ }^{1}$, TERESA STARZYŃSKA ${ }^{1}$ and MARIUSZ Z. RATAJCZAK ${ }^{3,4}$ \\ Departments of ${ }^{1}$ Gastroenterology and ${ }^{2}$ Physiology, Pomeranian Medical University, 71-252 Szczecin, Poland; \\ ${ }^{3}$ James Graham Brown Cancer Center, University of Louisville, Louisville, KY 40202, USA; \\ ${ }^{4}$ Department of Regenerative Medicine, Warsaw Medical University, 02-091 Warsaw, Poland
}

Received April 30, 2016; Accepted June 11, 2016

DOI: $10.3892 /$ or.2016.5179

\begin{abstract}
Bone marrow (BM) residing stem cells are mobilized from their BM niches into peripheral blood (PB) in several pathological situations including tissue organ injury and systemic inflammation. We recently reported that the number of BM-derived stem cells (SCs) increases in patients with pancreatic and stomach cancer. Accordingly, we observed higher numbers of circulating very small embryonic/ epiblast-like stem cells (VSELs) and mesenchymal stem cells (MSCs) that were associated with the activation of pro-mobilizing complement cascade and an elevated level of sphingosine-1 phosphate (S1P) in PB plasma. We wondered if a similar correlation occurs in patients with colorectal cancer (CRC). A total of 46 patients were enrolled in this study: 17 with CRC, 18 with benign colonic adenomas (BCA) and 11 healthy individuals. By employing fluorescenceactivated cell sorting (FACS) we evaluated the number of BM-derived SCs circulating in PB: i) $\mathrm{CD}^{2} 4^{+} / \mathrm{Lin}^{-} / \mathrm{CD} 45^{-}$and CD133 $/ \mathrm{Lin}^{-} / \mathrm{CD} 45^{-}$VSELs; ii) CD $45^{-} / \mathrm{CD} 105^{+} / \mathrm{CD}^{2} 0^{+} / \mathrm{CD} 29^{+}$ $\mathrm{MSC}$; iii) $\mathrm{CD} 45^{\circ} / \mathrm{CD} 34^{+} / \mathrm{CD} 33^{+} / \mathrm{KDR}^{+}$endothelial progenitor cells (EPCs); and iv) $\mathrm{CD} 133^{+} / \mathrm{Lin}^{-} / \mathrm{CD} 45^{+}$or $\mathrm{CD} 34^{+} / \mathrm{Lin}^{-} / \mathrm{CD} 45^{+}$ cells enriched for hematopoietic stem/progenitor cells (HSPCs). In parallel, we measured in the $\mathrm{PB}$ parameters regulating the egress of SCs from BM into PB. In contrast to pancreatic and gastric cancer patients, CRC subjects presented neither an increase in the number of circulating SCs nor the activation of pro-mobilizing factors such as complement, coagulation and fibrinolytic cascade, circulating stromal derived factor 1 (SDF-1), vascular endothelial growth factor (VEGF) and intestinal permeability marker (zonulin). In conclusion, mobilization of SCs in cancer patients depends on the type
\end{abstract}

Correspondence to: Dr Wojciech Marlicz, Department of Gastroenterology, Pomeranian Medical University, Unii Lubelskiej 1, 71-252 Szczecin, Poland

E-mail: marlicz@hotmail.com

Key words: colorectal cancer, stem cell mobilization, very small embryonic-like stem cells, mesenchymal stem cells, complement cascade of malignancy and its ability to activate pro-mobilization cascades.

\section{Introduction}

Colorectal cancer (CRC) is among the most commonly diagnosed cancers worldwide and the incidence is reported to be increasing in the coming years and it is the third most common cancer in men and the second in women worldwide (1). The current concepts concerning CRC pathogenesis revolve around stem cells (SCs), the role of innate immunity and microbiome alterations (2). The intrinsic (mutations of somatic SCs) and extrinsic (environmental) factors contribute to the development of cancer through the process of SC mutation/activation, where the rare population of cancer-initiating SCs emerging is responsible for the development, growth and metastatic spread $(3,4)$. Notably, in one of the published studies not locally residing SCs but bone marrow (BM)-derived ones, played an important role in the initiation of gastric cancer in a murine model (5).

The fact that very rare putative cancer SCs may circulate in the peripheral blood (PB) is already well known (6). Nevertheless, the role of non-mutated normal SCs in cancer progression is still under debate. It is more and more evident that circulating PB normal BM-derived SCs may play an important role in the vascularization of the growing tumor as well as in its stromalization $(7,8)$. In the vascularization of the growing tumor, circulating endothelial progenitor cells (EPCs) are directly involved and in the process of tumor tissue stromalization circulating mesenchymal stem cells (MSCs) are involved. Both populations of cells could be mobilized as demonstrated from $\mathrm{BM}$ into $\mathrm{PB}$ in response to tissue/organ injury (8-10). In addition to EPCs and MSCs, tissue organ injury mobilizes hematopoietic stem/progenitor cells (HSPCs) that may provide several soluble trophic factors for growing tumor cells (11). All these types of SCs are also a source of extracellular microvesicles (ExMVs) that directly affect proliferation and survival of cancer cells. In addition to the SCs aforementioned, BM harbors a population of developmental early very small SCs, that express several pluripotent- and multipotent-cell markers (12). These cells were described by our team as very small embryonic-like stem 
cells (VSELs) $(13,14)$. These small cells have been reported to be the precursors of MSCs, HSPCs and EPCs $(15,16)$. VSELs similarly, as other more differentiated and committed SCs, are mobilized into the $\mathrm{PB}$ in response to inflammation and tissue organ injuries $(17,18)$.

Since tumor growth is accompanied by tissue organ hypoxia and damage, we aimed to ascertain whether normal SCs could also be mobilized into the PB during tumor growth and expansion. In fact by employing an animal model of human sarcoma cells inoculated in immunodeficient mice we noted that several types of BM-residing SCs including VSELs were mobilized into the PB (19). Based on this we wondered whether a similar situation occurs in patients diagnosed with cancer and learned that both VSELs and MSCs are preferentially mobilized into the PB in pancreatic and stomach cancer patients $(20,21)$.

The mobilization of SCs from the BM into the PB requires the activation of several mechanisms related to innate immunity. It has been demonstrated that a crucial role in this process is played by the activation of a complement cascade and its activation is supported by two other ancient proteolytic cascades such as the coagulation and fibrinolytic cascade (22). Complement cleavage fragments, in particular C5 cleavage fragments $\mathrm{C} 5 \mathrm{a}$ and ${ }_{\text {desArg }} \mathrm{C} 5 \mathrm{a}$, are crucial in releasing SCs from BM into PB. SCs that egress from the BM, depending on their type, respond subsequently to plasma chemoattractants such as stromal derived factor-1 (SDF-1), vascular endothelial growth factor (VEGF) and hepatocyte growth factor (HGF). In addition sphingosine-1 phosphate (S1P) also plays a crucial role in the egress of SCs (22).

In the present study we evaluated a number of various types of BM-derived SCs (VSELs, MSCs, EPCs, HSPCs) as well as factors (such as activation of a complement cascade) in $\mathrm{CRC}$ patients as compared to individuals with benign colonic adenomas (BCA) and healthy controls. Our data indicated that in contrast to pancreatic and stomach cancer patients, individuals suffering from CRC demonstrate neither an increase in the number of circulating SCs nor an activation of a complement cascade. Based on this, we conclude that mobilization of $\mathrm{SCs}$ in cancer patients depends on the type of malignancy and its ability to activate pro-mobilization cascades.

\section{Materials and methods}

Study patients. Our study was approved by the Medical Ethics Committee of the Pomeranian Medical University and followed international and national regulations in accordance with the Declaration of Helsinki. All patients provided written informed consent before enrollment in this study. In total, 46 patients undergoing colonoscopy at the Department of Gastroenterology at Pomeranian Medical University between 2013 and 2014 were enrolled in the study. Eighteen patients diagnosed with BCA and 17 patients diagnosed with CRC at a time of their colonoscopic examination confirmed by histopathologic analysis, and 11 age-matched healthy controls with no lesions in the colon were recruited for the study. In the group of patients with BCA only those patients with one or more adenomas with a diameter $>10 \mathrm{~mm}$ were included in the study. All adenomas detected qualified for endoscopic snare polypectomy or were removed either with endoscopic mucosal resection (EMR) or endoscopic submucosal dissection (ESD). EMR and ESD resection quality were confirmed by histopathological examination and regarded as complete polyp removal. Patients exhibiting serious or systemic infections, severe disabilities, mental illness or undergoing chemotherapy or radiotherapy in the last 18 months were excluded from the study. In patients with confirmed colon cancer histopathology the staging was further assessed with the aid of abdominal ultrasonography, computed tomography and X-ray examinations. Fifteen patients diagnosed with colon cancer qualified for surgical removal of the colonic tumor and two patients qualified for radiotherapy or chemotherapy or other palliative treatments due to the advanced stage of the disease. Sixteen patients had their tumor localized in the left side of the colon and one had a tumor relapse at the site of anastomosis in the transverse colon. Additionally, the metabolic status of the patients, including body mass index (BMI) and history of diabetes mellitus, arterial hypertension and other comorbidities, as well as medicinal use and past surgery were recorded.

After completion of the endoscopic examination, PB samples $(8-10 \mathrm{ml})$ were obtained from the patients. The absolute number of leukocytes and lymphocytes in the PB were determined at the same time with an automatic cell counter (Beckman Coulter). Serum samples for measuring VEGF, HGF, C5a, SDF-1 zonulin, plasmin-antiplasmin (PAP) and thrombin-antithrombin (TAT) levels were also frozen and stored at $-80^{\circ} \mathrm{C}$ for further analysis.

Flow cytometry. Circulating cells expressing i) $\mathrm{CD}^{+} 4^{+}$and $\mathrm{CD}_{133^{+}}$a population of $\mathrm{Lin}^{-} \mathrm{CD} 45^{-} \mathrm{VSELs}$; ii) $\mathrm{CD} 45^{-} / \mathrm{CD}^{\circ} 5^{+} /$ $\mathrm{CD} 90^{+} / \mathrm{CD} 29^{+}$a population of $\mathrm{MSCs}$; iii) $\mathrm{CD} 45 / \mathrm{CD} 34^{+} /$ $\mathrm{CD} 33^{+} / \mathrm{KDR}^{+}$a population of EPCs; and iv) $\mathrm{CD} 133^{+} / \mathrm{Lin} /$ $\mathrm{CD} 45^{+}$or $\mathrm{CD} 34^{+} / \mathrm{Lin}^{-} / \mathrm{CD} 45^{+}$cells enriched for HSPCs were identified as previously described $(20,23)$. Briefly these cells were identified following immunostaining of the whole PB-derived nucleated cell fraction against hematopoietic lineage markers (Lin), CD45 antigen (PE; clone HI3, BD Biosciences), CD133 (APC; clone CD133/1, Miltenyi Biotec, Bergisch Gladbach, Germany), or CD34 (APC; clone 581, BD Biosciences). Antibodies for Lin markers included the following fluorescein isothiocyanate (FITC)-conjugated murine anti-human antibodies: anti-CD2 (clone RPA-2.10), anti-CD3 (clone UCHT1), anti-CD14 (clone M5E2), anti-CD66b (clone G10F5), anti-CD24 (clone ML5), anti-CD56 (clone NCAM16.2), anti-CD16 (clone 3G8), anti-CD19 (clone HIB19), and anti-CD235a (clone GA-R2). Staining for EPCs (CD $45 / \mathrm{CD} 31^{+} / \mathrm{CD} 133^{+}$and $\mathrm{CD} 45 / \mathrm{CD} 31^{+} / \mathrm{CD} 34^{+} / \mathrm{KDR}^{+}$cells) was performed with fluorescent-labeled antibodies for CD45 antigen (FITC, clone HI3; BD Biosciences), CD31 (PE, clone WM59; BioLegend, San Diego, CA, USA), CD133 (APC, clone CD133/1; Miltenyi Biotec), CD34 (PE-Cy5, clone 581; BD Biosciences), and KDR (also known as VEGFR2, APC, clone 89106; R\&D Systems, Minneapolis, MN, USA), while the labeling of MSCs employed antibodies, such as CD45 (FITC, clone HI3; BD Biosciences), CD105 (PE, clone 43A3; BioLegend), and Stro-1 (Alexa Fluor 647, clone STRO-1; BioLegend).

Additionally, a single-cell suspension was stained for lineage markers (CD56, CD235a, CD3, CD66b, CD24, CD19, 
Table I. General characteristics of the patients enrolled in the study.

\begin{tabular}{|c|c|c|c|}
\hline $\begin{array}{l}\text { Patient } \\
\text { characteristics }\end{array}$ & $\begin{array}{l}\text { Benign colonic } \\
\text { adenomas }(n=18)\end{array}$ & $\begin{array}{c}\text { Colorectal } \\
\text { cancer }(n=17)\end{array}$ & $\begin{array}{c}\text { Healthy } \\
\text { controls }(n=11)\end{array}$ \\
\hline Age (years) & $65 \pm 11$ & $65 \pm 9$ & $50 \pm 17$ \\
\hline \multicolumn{4}{|l|}{ Gender } \\
\hline Male & 9 & 8 & 7 \\
\hline Female & 9 & 9 & 4 \\
\hline BMI $\left(\mathrm{kg} / \mathrm{m}^{2}\right)$ & $26.8 \pm 4.16$ & $28.3 \pm 5.87$ & $26.8 \pm 3.09$ \\
\hline Non-smoker & 18 & 15 & 11 \\
\hline Histological type & $\begin{array}{l}\text { Tubular adenoma, villous, } \\
\text { tubulovillous }\end{array}$ & Adenocarcinoma & $\begin{array}{c}\text { No colonic lesions } \\
\text { in colonoscopy }\end{array}$ \\
\hline Grade of dysplasia & Minor to major & $\mathrm{G} 2-3$ & N/A \\
\hline Mean size (mm) & $22.8 \pm 9.62$ & N/A & N/A \\
\hline $\begin{array}{l}\text { Type of removal } \\
\text { endoscopic vs. surgery }\end{array}$ & $\begin{array}{c}\text { Snare polypectomy } \\
\text { EMR/ESD }\end{array}$ & Surgery $(n=15)$ & N/A \\
\hline Staging/Aster-Coller (AC) & $\mathrm{N} / \mathrm{A}$ & & $\mathrm{N} / \mathrm{A}$ \\
\hline Stage I (B1) & & 1 & \\
\hline Stage II A-C (B2) & & 12 & \\
\hline Stage III A-C (C1/C2) & & 2 & \\
\hline Stage IV A-B & & 2 & \\
\hline
\end{tabular}

Data are provided as means \pm SD or number. BMI, body mass index; N/A, non-applicable; EMR, endoscopic mucosal resection; ESD, endoscopic submucosal dissection.

CD14, CD16, and CD2) conjugated with FITC, CD45 conjugated with PE, for $30 \mathrm{~min}$ on ice. After being washed, the cells were analyzed by FACS (Navios; Beckman Coulter). At least $10^{6}$ events were acquired and analyzed by Kaluza software.

Plasma concentrations of complement cascade protein cleavage fragments, intestinal permeability markers, plasmin/thrombin complexes and growth factors. The concentration of the complement cascade C5a cleavage fragments, SDF-1, HGF, VEGF, PAP, TAT complexes and zonulin were measured using commercially available, high-sensitivity enzyme-linked immunosorbent assay (ELISA) kits such as the C5a Quantikine human immunoassays, HGF Quantikine human immunoassays, and VEGF Quantikine human immunoassays (R\&D Systems), as well as the PAP and TAT Quantikine human immunoassays, SDF-1 and zonulin Quantikine human immunoassays according to the manufacturer's protocol.

Statistical analysis. For the purpose of determining the distribution of the continuous variables analyzed, the Shapiro-Wilk's test was employed. For comparison of the mean parameter values between the examined groups (for normally distributed variables), a Student's t-test was used. For variables that were not normally distributed, the variable values were logtransformed. If a normal distribution was then achieved, these transformed variables were also compared using a Student's t-test. However, if the transformation did not create a normal distribution, the Mann-Whitney U test was performed. When the parameters were compared among more than two groups, the Kruskal-Wallis ANOVA and post hoc tests were used. Correlations between various analyzed parameters were calculated using Pearson's test or Spearman's rank test, according to the normality of the distribution. In order to evaluate the effect(s) of continuous variables on the numbers of circulating SCs and immunomodulatory complexes, multivariate regression analyses with a stepwise selection method was utilized. Variables that were excluded from the initial model were reintroduced individually to exclude residual confounding variables. Statistical analysis was performed using Statistica 12 PL software (StatSoft) and significance was defined as $\mathrm{P}<0.05$.

\section{Results}

General characteristics of the healthy controls and the patients with BCA and CRC. General characteristics and medical history of the patients recruited for the study are listed in Tables I and II. All patients recruited for the study signed written consent and underwent a colonoscopy at the Department of Gastroenterology, Pomeranian Medical University. Those diagnosed with polyps were qualified either for snare polypectomy, EMR or ESD. In all cases of BCA, complete endoscopic removal was possible and confirmed by pathomorphological analysis. Patients with CRC were assessed before and after surgery and qualified according to the staging of their CRC: 1 patient with Astler-Coller B1 (stage I); 12 patients with Astler-Coller B2 (stage II), 2 patients with 
Table II. Medical history of patients enrolled in the study.

\begin{tabular}{llll}
\hline $\begin{array}{l}\text { Patient } \\
\text { medical history }\end{array}$ & BCA & CRC & $\begin{array}{l}\text { Healthy } \\
\text { controls }\end{array}$ \\
\hline $\begin{array}{l}\text { Comorbidities } \\
\text { Diabetes mellitus }\end{array}$ & 2 & 2 & 0 \\
Arterial hypertension & 6 & 5 & 0 \\
Myocardial infarction & 1 & 0 & 0 \\
Peptic ulcer & 1 & 0 & 0 \\
Asthma & 1 & 0 & 0 \\
Prior surgery & & & \\
Hysterectomy & 1 & 0 & 1 \\
Cholecystectomy & 0 & 2 & 0 \\
History of medicinal use & & & \\
Antiglicaemics & 2 & 1 & 0 \\
Antihypertensive & 3 & 3 & 0 \\
$\quad$ Antibiotics & 0 & 1 & 0 \\
Family history of cancer & & & \\
Colon cancer & 1 & 1 & 1 \\
Gastric cancer & 1 & 0 & 0 \\
Lung cancer & 1 & 1 & 0 \\
Pancreatic cancer & 2 & 1 & 0 \\
\hline BCA & & & \\
\hline
\end{tabular}

BCA, benign colonic adenomas; $\mathrm{CRC}$, colorectal cancer.

Astler-Coller C1 or C2 (stage III) and 2 patients with generalized disease (stage IV). All cancers except one were localized in the left site of the colon (rectum, sigmoid or descending colon). One patient had a relapse of CRC in the site of anastomosis after primary surgery due to CRC diagnosis in 2012. Patients diagnosed with CRC had lower values of hemoglobin concentration in their blood in comparison to the healthy controls and with the BCA groups. Also patients with CRC had higher levels of $\mathrm{C}$-reactive protein $(\mathrm{CRP})$ in comparison to other groups. Blood biochemical parameters are summarized in Table III.

Circulating SCs in patients with BCA, CRC and healthy individuals. To elucidate the role of non-mutated normal BM-derived SCs circulating in the PB of patients with colonic neoplasia, we evaluated by FACS the number of various populations of circulating cells enriched for HSPCs, MSCs, EPCs, and VSELs and compared the results with those obtained from age-matched healthy controls with no cancer lesions in their bowels (Table IV). In all the groups of patients studied we were able to detect rare populations of circulating cells enriched for HSPCs, MSCs, EPCs and VSELs. However we did not observe a significant increase in the mobilization of any population of cells studied. Moreover, neither body metabolic status, such as BMI nor comorbid diseases including diabetes mellitus, affected the number of circulating SCs in subjects evaluated in this study. Moreover, patients with CRC characterized by lower blood hemoglobin levels (lower normal range of hemoglobin values) and higher levels of inflammatory markers (CRP) did not show significant variations in the number of SCs mobilized into the PB.
Plasma concentrations of factors regulating the egress of SCs from the BM into the $P B$ in patients with colon cancer and healthy individuals. SCs that egress from the BM, pending on their type, respond to several plasma chemoattractants such as SDF-1, VEGF and HGF. To validate this observation, we employed ELISA to measure the plasma concentrations of VEGF, HGF, SDF-1 in plasma of patients with CRC as well as in healthy individuals. Additionally, we measured the plasma concentration of zonulin which is a marker of intestinal permeability (Tables V and VI). Our ELISA results revealed that plasma levels of VEGF, SDF-1 and zonulin did not differ between patients diagnosed with cancer and healthy individuals. However, plasma concentrations of HGF were significantly elevated in patients with colon cancer, but without the effect on a number of SCs circulating in the PB in the studied groups.

The mobilization of SCs in cancer patients depends on the type of malignancy and its ability to activate pro-mobilization cascades. We previously demonstrated the crucial role of the activation of complement cascade cleavage fragments $\mathrm{C} 5 \mathrm{a}$ in the release of SCs from the BM into the PB in patients with pancreatic and stomach cancer. Thus the release of SCs into the PB could be viewed as part of a complement cascademediated immune response to inflammation and/or tissue damage. Since we did not observe an increase in the number of circulating SCs in CRC patients, we wondered if this could be explained by the lack of complement cascades as well as other SC mobilization-supporting proteolytic cascades such as the coagulation and fibrinolytic cascades (20) that affect the egress of SCs from the BM into the PB.

Data presented in Table VI demonstrate that we did not observe the activation of a complement cascade and the plasma concentration of C5 cleavage fragment. Anaphylatoxin C5a was even lower when compared to BCA patients and control subjects. Similarly no significant changes were noted in concentrations in the TAT and PAP complexes (Table VI). Finally, no changes were observed in the zonulin and SDF-1 levels.

HSPCs are not mobilized in CRC patients. As demonstrated in Table IV we did not observe, by employing a FACS analysis, an increase in the $\mathrm{PB}$ in the number of circulating CD $344^{+} / \mathrm{Lin}^{-} / \mathrm{CD} 45^{+}$or $\mathrm{CD} 133^{+} / \mathrm{Lin}^{-} / \mathrm{CD} 45^{+} \mathrm{HSPCs}$. To address this better we performed in vitro colony assays (24) to ascertain whether the number of clonogenic progenitors for erythroid (BFU-E) and granulocyte-monocyte (CFU-GM) are unaffected by growing CRC. As shown in Table VII no changes in the number of these cells circulating in the PB were observed between the study groups.

\section{Discussion}

The observation that normal SCs play a role in cancer progression is intriguing; however more direct evidence is still needed. It has been proposed that normal BM-derived SCs circulating in PB play an important role in tumor initiation, progression and metastasis. To support this Houghton et al reported that BM-derived SCs may repopulate the gastric epithelium in response to chronic inflammation and subsequently in some cases this may lead to malignant transformation and the development of stomach cancer (5). 
Table III. Biochemical blood results of the patients enrolled in the study (means \pm SD)

\begin{tabular}{|c|c|c|c|c|}
\hline Biochemical results & $\begin{array}{c}\text { BCA } \\
(n=18)\end{array}$ & $\begin{array}{l}\text { CRC } \\
(n=17)\end{array}$ & $\begin{array}{l}\text { Healthy controls } \\
\qquad(\mathrm{n}=11)\end{array}$ & Significance \\
\hline WBC count $\left(\times 10^{9}\right.$ cells $\left./ 1\right)$ & $6.67 \pm 1.31$ & $7.22 \pm 2.68$ & $6.85 \pm 3.28$ & NS \\
\hline RBC count $\left(\times 10^{12}\right.$ cells/l) & $4.76 \pm 0.46$ & $4.55 \pm 0.41$ & $4.81 \pm 0.64$ & NS \\
\hline $\operatorname{Hgb}(\mathrm{g} / \mathrm{dl})$ & $14.24 \pm 1.29^{\mathrm{a}}$ & $12.57 \pm 1.64^{\mathrm{a}}$ & $14.47 \pm 1.67$ & $\mathrm{P}<0.05^{\mathrm{a}}$ \\
\hline $\operatorname{MCV}(f \mathrm{fl})$ & $89.56 \pm 2.35$ & $85.06 \pm 6.90$ & $82.36 \pm 22.52$ & NS \\
\hline Platelet count $\left(\times 10^{9}\right.$ cells $\left./ \mathrm{l}\right)$ & $208.46 \pm 60.82$ & $248.30 \pm 68.12$ & $254.75 \pm 69.42$ & NS \\
\hline $\operatorname{ALT}(\mathrm{U} / \mathrm{l})$ & $27.6 \pm 25.58$ & $17.0 \pm 4.64$ & $20.85 \pm 9.15$ & NS \\
\hline AST (U/l) & $30.71 \pm 19.44$ & $22.6 \pm 5.94$ & $20.42 \pm 5.22$ & NS \\
\hline CRP (mg/l) & $3.18 \pm 2.44$ & $12.62 \pm 19.01^{\mathrm{a}}$ & $1.53 \pm 0.97^{\mathrm{a}}$ & $\mathrm{P}<0.05^{\mathrm{a}}$ \\
\hline
\end{tabular}

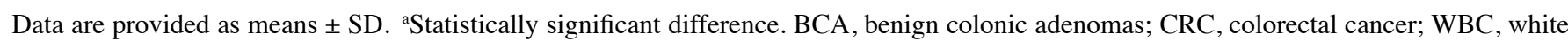
blood count; RBC, red blood count; MCV, mean corpuscular volume; ALT, alanine aminotransferase; AST, aspartate aminotransferase; CRP, C-reactive protein; NS, no statistically significant difference.

Table IV. Absolute numbers of circulating early progenitor/stem cells in peripheral blood of the patients and healthy controls.

\begin{tabular}{|c|c|c|c|c|}
\hline Study cell population & $\mathrm{BCA}$ & CRC & Healthy controls & Significance \\
\hline \multicolumn{5}{|l|}{ HSPCs } \\
\hline $\mathrm{CD} 34^{+} / \mathrm{Lin}^{-} / \mathrm{CD} 45^{+}$ & $1.215(0.799)$ & $1.020(1.110)$ & $0.869(0.544)$ & $\mathrm{P}>0.05 \mathrm{NS}$ \\
\hline $\mathrm{CD} 133^{+} / \mathrm{Lin}^{-} / \mathrm{CD} 45^{+}$ & $0.830(0.584)$ & $0.843(0.894)$ & $0.893(0.629)$ & $\mathrm{P}>0.05 \mathrm{NS}$ \\
\hline \multicolumn{5}{|l|}{ MSCs } \\
\hline $\mathrm{CD} 45^{-} / \mathrm{CD} 105^{+} / \mathrm{CD} 90^{+} / \mathrm{CD} 29^{+}$ & $0.098(0.07)$ & $0.166(0.13)$ & $0.088(0.07)$ & $\mathrm{P}>0.05 \mathrm{NS}$ \\
\hline \multicolumn{5}{|l|}{ EPCs } \\
\hline $\mathrm{CD} 45^{-} / \mathrm{CD}_{3} 4^{+} / \mathrm{CD} 133^{+} / \mathrm{KDR}^{+}$ & $0.142(0.119)$ & $0.191(0.119)$ & $0.154(0.141)$ & $\mathrm{P}>0.05 \mathrm{NS}$ \\
\hline \multicolumn{5}{|l|}{ VSELs } \\
\hline $\mathrm{CD} 34^{+} / \mathrm{Lin}^{-} / \mathrm{CD} 45^{-}$ & $0.076(0.051)$ & $0.114(0.079)$ & $0.103(0.059)$ & $\mathrm{P}>0.05 \mathrm{NS}$ \\
\hline $\mathrm{CD} 133^{+} / \mathrm{Lin}^{-} / \mathrm{CD} 45^{-}$ & $0.057(0.044)$ & $0.082(0.054)$ & $0.071(0.057)$ & $\mathrm{P}>0.05 \mathrm{NS}$ \\
\hline
\end{tabular}

Data are expressed as the number of cells per microliter of blood (mean standard deviation). Statistical analysis was performed using SPSS statistical analysis software and significance was defined as $\mathrm{P}<0.05$. BCA, benign colonic adenomas; CRC, colorectal cancer; HSPCs, hematopoietic stem progenitor cells; MSCs, mesenchymal stem cells; EPCs, endothelial progenitor cells; VSELs, very small embryonic-like stem cells; P, level of significance; NS, no statistically significant difference.

Table V. Plasma concentrations of VEGF and HGF in patients with colorectal cancer and healthy controls.

\begin{tabular}{lccc}
\hline Cytokine & CRC & $\begin{array}{l}\text { Healthy } \\
\text { controls }\end{array}$ & Significance \\
\hline VEGF $(\mathrm{pg} / \mathrm{ml})$ & $188.38 \pm 128.11$ & $150.38 \pm 76.48$ & $\mathrm{NS}$ \\
HGF $(\mathrm{pg} / \mathrm{ml})$ & $3,248 \pm 604^{\mathrm{a}}$ & $2,358 \pm 334^{\mathrm{a}}$ & $\mathrm{P}<0.01^{\mathrm{a}}$ \\
\hline
\end{tabular}

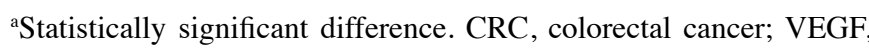
vascular endothelial growth factor; HGF, hepatocyte growth factor; NS, no statistically significant difference.

Mounting evidence has also revealed that the number of normal SCs increases in the PB as a 'malignancy-accompanying phenomenon' in response to the growth of some tumors. Previously, we demonstrated that this occurs, for example, in immunodeficient mice inoculated with human sarcoma (19), as well as in our clinical studies in patients with pancreatic $(20,25)$ and stomach cancer $(21,26)$. It is well known that the number of normal SCs in PB increases during several pathological conditions including, for example, tissue/organ damage $(10,17,18)$. Since expanding hypoxic tumor microenvironment mimics hypoxic/damaged tissue this may explain the mobilization of a variety of SCs from the BM into the PB, as an attempt 'to repair' these lesions. Another mechanism that may be involved here is the release of several potential chemoattractants by cancer tissue itself that may facilitate the egress of SCs. What is also important, is SC mobilization in cancer patients may be triggered due to the activation of three evolutionary ancient proteolytic cascades: the complement cascade, coagulation cascade and fibrinolytic cascade $(27,28)$.

It is well known that BM harbors several types of SCs (29). The most common are HSPCs, MSCs and EPCs. In addition to these cells, our group identified in human BM a very rare 
Table VI. Plasma concentrations of PAP and TAT complexes, C5a and SDF-1 in patients with benign colonic adenomas, colorectal cancer and healthy controls.

\begin{tabular}{lcccc}
\hline Cytokine & BCA & CRC & Healthy controls & Significance \\
\hline C5a $(\mathrm{pg} / \mathrm{ml})$ & $9.94 \pm 5.32$ & $3.81 \pm 0.85^{\mathrm{a}}$ & $12.83 \pm 2.51^{\mathrm{a}}$ & $\mathrm{P}<0.00001^{\mathrm{a}}$ \\
TAT $(\mathrm{ng} / \mathrm{ml})$ & $13.39 \pm 3.07$ & $17.68 \pm 9.72$ & $12.09 \pm 1.82$ & $\mathrm{P}>0.05 \mathrm{NS}$ \\
PAP $(\mathrm{ng} / \mathrm{ml})$ & $541.81 \pm 229.20$ & $671.85 \pm 307.91$ & $650.83 \pm 249.14$ & $\mathrm{P}>0.05 \mathrm{NS}$ \\
SDF-1 $(\mathrm{pg} / \mathrm{ml})$ & $1,718 \pm 316$ & $1,692 \pm 437$ & $1,748 \pm 249$ & $\mathrm{P}>0.05 \mathrm{NS}$ \\
Zonulin $(\mathrm{ng} / \mathrm{ml})$ & $10.74 \pm 1.24$ & $12.13 \pm 3.80$ & $9.98 \pm 1.70$ & $\mathrm{P}>0.05 \mathrm{NS}$ \\
\hline
\end{tabular}

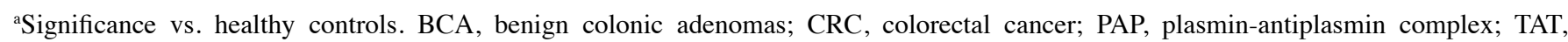
thrombin-antithrombin complex; SDF-1, stromal derived factor 1; NS, no statistically significant difference.

Table VII. Clonogenic assays derived from BM-MNCs in patients with benign colonic neoplasia, colorectal cancer and healthy controls.

\begin{tabular}{lcccr}
\hline Clonogenic assay & Benign colonic neoplasia & CRC & Healthy controls & P-value \\
\hline BFU-E & $89.82 \pm 63.19$ & $67.88 \pm 50.38$ & $82.11 \pm 86.28$ & P $>0.05$ \\
CFU-GM & $5.70 \pm 6.25$ & $4.82 \pm 3.24$ & $10.22 \pm 14.56$ & P $>0.05$ \\
\hline
\end{tabular}

BM, bone marrow; CRC, colorectal cancer; BFU-E, burst-forming unit of erytrhrocyte; CFU-GM, colony-forming unit of granulocytes and macrophages.

population such as $\mathrm{CD}_{133^{+}}, \mathrm{CD}_{3} 4^{+}, \mathrm{CXCR}^{+}, \mathrm{Lin}^{-}, \mathrm{CD} 45$ that have been named VSELs (13). These small cells express several markers of pluripotent stem cells (PSCs) including SSEA-1, Oct-4, Nanog and Rex-1. These early human cells or their murine counterparts were found to differentiate into cells of all three germ-layer lineages and may give rise to all other types of BM-residing SCs (HSPCs, MSCs and EPCs) $(12,15,16)$.

All these BM-residing SCs types, when released into the circulation, may potentially directly or indirectly affect tumor growth. Firstly, they may promote the vascularization of expanding tumor tissue (MSCs, VSELs) and its stromalization (MSCs, VSELs) $(30,31)$. On the other hand, all these types of SCs including HSPCs may release several growth factors, chemokines and bioactive lipids that promote growth, vascularization and inhibit the apoptosis of expanding tumor cells (32). To support this, we previously demonstrated that normal BM-derived CD34 ${ }^{+}$HSPCs are a source of several trophic and angiopoietic factors (33). SCs may also release ExMVs that also provide similar biological activities to the aforementioned soluble factors (34). On the other hand, circulating HSPCs may also give rise to cells (e.g., NK cells) that are involved in the inhibition of tumor expansion (35). Therefore, the effects of the mobilized SCs in the PB and the circulating SCs are pleiotropic as they may propagate as well as control tumor cell growth (36).

Recently, tremendous effort has been made to better understand the mechanisms affecting the egress of SCs from the $\mathrm{BM}$ into the PB. Accumulated evidence has revealed that the activation of a complement cascade plays a crucial role in this process. This proteolytic cascade is a part of innate immunity and regulates several processes related to infection (37) and organ/tissue development and regeneration (38). To support this notion it has been demonstrated that mice which are deficient in the $\mathrm{C} 5$ component of the complement cascade are poor mobilizers (39) and efficient mobilization of SCs in patients is correlated with cleavage of $\mathrm{C} 5$ and generation of potent anaphylatoxin $\mathrm{C} 5 \mathrm{a}$ and ${ }_{\text {desArg }} \mathrm{C} 5 \mathrm{a}$ (27). As aforementioned, thrombin and plasmin also possess $\mathrm{C} 5$ convertase activity and can cleave C5a into bioactive C5a and ${ }_{\text {desArg }} \mathrm{C} 5 \mathrm{a}$ peptides (40). Therefore, both the coagulation and fibrinolysis cascade also play a supportive role in the SC mobilization process (27).

Herein, surprisingly in contrast to our previous studies, where we have demonstrated that SCs are mobilized into the $\mathrm{PB}$ in pancreatic and stomach cancer, the number of circulating SCs in the PB in CRC patients was similar as that noted in the BCA and the healthy control subjects. To explain this discrepancy we did not observe in CRC patients activation of the complement, coagulation and fibrinolytic cascades. As reported previously, the complement cascade was activated in patients suffering from pancreatic and stomach cancer $(20,26)$. This therefore explains that due to the lack of activation of pro-mobilizing cascades, SCs in CRC were not mobilized. However, we cannot rule out that this may change if any additional complications occur in these subjects, such as accompanying systematic infections or intestinal inflammation. One of the potential triggers for SC mobilization is radio- chemotherapy (41-43). We recently demonstrated that the number of circulating SCs increases in patients suffering from active Crohn's disease (44). In addition to the pro-mobilizing effects of $\mathrm{C} 5$ cleavage fragments, 
activation of a complement cascade may affect several other aspects of tumor metastasis. As reported, the blockade of C5a-C5a receptor axis with monoclonal antibodies impairs tumor metastasis (45). In view of this, we observed that the C5a level in our CRC patients was lower when compared to the control group. These observations reflect the natural history and correspond to the prognosis of gastrointestinal cancers studied by our group $(20,26,46)$. Most of our patients in the present study who were diagnosed with CRC at the time of their colonoscopy were free from metastatic spread. In contrast, the majority of patients with pancreatic and stomach cancers were manifesting an advanced stage of the disease at the time of diagnosis $(47,48)$.

Egress of SCs from the BM is also regulated by an increase in certain chemotactic factors in the PB. Nevertheless, in our studies we did not observe an increase in SDF-1 or VEGF levels that are potent SC chemoattractants $(20,25,26,44)$. However, we observed an increase in the HGF level, but its concentration obviously was not sufficient to release SCs from the $\mathrm{BM}$ into the PB. The overall low level of pro-mobilizing SDF-1 and VEGF in the PB may also change, if some additional complications occur, and this can affect, in such cases, the number of SCs circulating in the PB.

In conclusion, the mobilization of SCs in the PB in cancer patients depends on the tumor type and the clinical status of the patient. In contrast to pancreatic and stomach cancer patients, the number of circulating SCs in CRC was similar as that noted in the BCA and the healthy subjects. This could be explained by the lack of activation of pro-mobilizing pathways in our subjects. However, we are aware that this may change for instance, if any additional complications occur, that will lead to the activation of a complement cascade and/or an increase of chemotactic factors in the PB.

\section{Acknowledgements}

This study from W.M., T.S. and M.Z.R was supported by a European Union grant (POIG.01.01.02-00-109/09) and Pomeranian Medical University in Szczecin. The research performed by M.Z.R was additionally supported by the Harmonia NCN grant: UMO-2014/14/M/NZ3/00475.

\section{References}

1. Ferlay J, Soerjomataram I, Dikshit R, Eser S, Mathers C, Rebelo M, Parkin DM, Forman D and Bray F: Cancer incidence and mortality worldwide: Sources, methods and major patterns in GLOBOCAN 2012. Int J Cancer 136: E359-E386, 2015.

2. Wang X, Yang Y and Huycke MM: Commensal bacteria drive endogenous transformation and tumour stem cell marker expression through a bystander effect. Gut 64: 459-468, 2015.

3. Tomasetti C and Vogelstein B: Variation in cancer risk among tissues can be explained by the number of stem cell divisions. Science 347: 78-81, 2015.

4. Wu S, Powers S, Zhu W and Hannun YA: Substantial contribution of extrinsic risk factors to cancer development. Nature 529: 43-47, 2016.

5. Houghton J, Stoicov C, Nomura S, Rogers AB, Carlson J, Li H, Cai X, Fox JG, Goldenring JR and Wang TC: Gastric cancer originating from bone marrow-derived cells. Science 306 : 1568-1571, 2004.

6. Hardingham JE, Grover P, Winter M, Hewett PJ, Price TJ and Thierry B: Detection and clinical significance of circulating tumor cells in colorectal cancer-20 years of progress. Mol Med 21 (Suppl 1): S25-S31, 2015.
7. Li HC, Stoicov C, Rogers AB and Houghton J: Stem cells and cancer: Evidence for bone marrow stem cells in epithelial cancers. World J Gastroenterol 12: 363-371, 2006.

8. Donnelly JM, Engevik A, Feng R, Xiao C, Boivin GP, Li J, Houghton $\mathrm{J}$ and Zavros Y: Mesenchymal stem cells induce epithelial proliferation within the inflamed stomach. Am J Physiol Gastrointest Liver Physiol 306: G1075-G1088, 2014.

9. Kaźmierski M, Tendera M, Podolecka E, MichalewskaWłudarczyk A, Lasek-Bal A and Wojakowski W: Is there a relationship between exercise-induced endothelial progenitor cell mobilization and cytokine concentrations in patients with premature coronary heart disease? [corrected]. Pol Arch Med Wewn 125: 305-307, 2015.

10. Paczkowska E, Gołąb-Janowska M, Bajer-Czajkowska A, Machalińska A, Ustianowski P, Rybicka M, Kłos P, Dziedziejko V, Safranow K, Nowacki P, et al: Increased circulating endothelial progenitor cells in patients with haemorrhagic and ischaemic stroke: The role of endothelin-1. J Neurol Sci 325: 90-99, 2013.

11. Marycz K, Mierzejewska K, Śmieszek A, Suszynska E, Malicka I, Kucia M and Ratajczak MZ: Endurance exercise mobilizes developmentally early stem cells into peripheral blood and increases their number in bone marrow: Implications for tissue regeneration. Stem Cells Int 2016: 5756901, 2016.

12. Kim Y, Jeong J, Kang H, Lim J, Heo J, Ratajczak J, Ratajczak MZ and Shin DM: The molecular nature of very small embryonic-like stem cells in adult tissues. Int J Stem Cells 7: 55-62, 2014.

13. Kucia M, Reca R, Campbell FR, Zuba-Sumra E, Majka M, Ratajczak J and Ratajczak MZ: A population of very small embryonic-like (VSEL) CXCR4 ${ }^{+}$SSEA- $1^{+}$Oct- $4^{+}$stem cells identified in adult bone marrow. Leukemia 20: 857-869, 2006.

14. Ratajczak MZ, Zuba-Surma EK, Wysoczynski M, Ratajczak J and Kucia M: Very small embryonic-like stem cells: Characterization, developmental origin, and biological significance. Exp Hematol 36: 742-751, 2008.

15. Guerin CL, Loyer X, Vilar J, Cras A, Mirault T, Gaussem P, Silvestre JS and Smadja DM: Bone-marrow-derived very small embryonic-like stem cells in patients with critical leg ischaemia: Evidence of vasculogenic potential. Thromb Haemost 113: 1084-1094, 2015.

16. Havens AM, Sun H, Shiozawa Y, Yung Y, Wang J, Mishra A, Jiang Y, O'Neill DW, Krebsbach PH, Rodgerson DO, et al: Human and murine very small embryonic-like cells represent multipotent tissue progenitors, in vitro and in vivo. Stem Cells Dev 23: 689-701, 2014.

17. Drukała J, Paczkowska E, Kucia M, Młyńska E, Krajewski A, Machaliński B, Madeja Z and Ratajczak MZ: Stem cells, including a population of very small embryonic-like stem cells, are mobilized into peripheral blood in patients after skin burn injury. Stem Cell Rev 8: 184-194, 2012.

18. Golipoor Z, Mehraein F, Zafari F, Alizadeh A, Ababzadeh S and Baazm M: Migration of bone marrow-derived very small embryonic-like stem cells toward an injured spinal cord. Cell J 17: 639-647, 2016.

19. Tarnowski M, Grymula K, Liu R, Tarnowska J, Drukala J, Ratajczak J, Mitchell RA, Ratajczak MZ and Kucia M: Macrophage migration inhibitory factor is secreted by rhabdomyosarcoma cells, modulates tumor metastasis by binding to CXCR4 and CXCR7 receptors and inhibits recruitment of cancer-associated fibroblasts. Mol Cancer Res 8: 1328-1343, 2010.

20. Starzyńska T, Dąbkowski K, Błogowski W, Zuba-Surma E, Budkowska M, Sałata D, Dołęgowska B, Marlicz W, Lubikowski J and Ratajczak MZ: An intensified systemic trafficking of bone marrow-derived stem/progenitor cells in patients with pancreatic cancer. J Cell Mol Med 17: 792-799, 2013.

21. Starzyńska T,Zuba-Surma E, Marlicz W, Błogowski W, Nowak W, Ławniczak M, Madej A, Deskur A, Dulak J and Ratajczak MZ: Very small embryonic/epiblast-like stem cells (VSELS) and multipotent mesenchymal stem cells (MSCS) are mobilized into peripheral blood in patients with gastric/pancreatic tumors. Gut 59 (Suppl 3): A107, 2010.

22. Ratajczak MZ, Lee H, Wysoczynski M, Wan W, Marlicz W, Laughlin MJ, Kucia M, Janowska-Wieczorek A and Ratajczak J: Novel insight into stem cell mobilization-plasma sphingosine-1-phosphate is a major chemoattractant that directs the egress of hematopoietic stem progenitor cells from the bone marrow and its level in peripheral blood increases during mobilization due to activation of complement cascade/membrane attack complex. Leukemia 24: 976-985, 2010 
23. Ratajczak MZ, Liu R, Marlicz W, Blogowski W, Starzynska T, Wojakowski $\mathrm{W}$ and Zuba-Surma E: Identification of very small embryonic/epiblast-like stem cells (VSELs) circulating in peripheral blood during organ/tissue injuries. Methods Cell Biol 103: 31-54, 2011.

24. Ratajczak MZ, Pletcher CH, Marlicz W, Machalinski B, Moore J, Wasik M, Ratajczak J and Gewirtz AM: CD34+, kit ${ }^{+}$, rhodamine123(low) phenotype identifies a marrow cell population highly enriched for human hematopoietic stem cells. Leukemia 12: 942-950, 1998

25. Starzynska T, Dabkowski K, Blogowski W, Zuba-Surma E, Salata D, Budkowska M, Marlicz W, Lubikowski J and Ratajczak MZ: Novel observation that complement cascade and plasma sphingosine-1-phosphate levels orchestrate mobilization of bone marrow-derived stem cells into peripheral blood in patients with pancreatic cancer. Gut 61 (Suppl 3): A44, 2012.

26. Błogowski W, Zuba-Surma E, Sałata D, Budkowska M, Dołęgowska B and Starzyńska T: Peripheral trafficking of bone-marrow-derived stem cells in patients with different types of gastric neoplasms. OncoImmunology 5: e1099798, 2015.

27. Borkowska S, Suszynska M, Ratajczak J and Ratajczak MZ: Evidence of a pivotal role for the distal part of the complement cascade in the diurnal release of hematopoietic stem cells into peripheral blood. Cell Transplant 25: 275-282, 2016.

28. Ratajczak MZ: A novel view of the adult bone marrow stem cell hierarchy and stem cell trafficking. Leukemia 29: 776-782, 2015.

29. Ratajczak MZ and Suszynska M: Emerging strategies to enhance homing and engrafment of hematopoietic stem cells. Stem Cell Rev 12: 121-128, 2016.

30. Ratajczak J, Wysoczynski M, Zuba-Surma E, Wan W, Kucia M Yoder MC and Ratajczak MZ: Adult murine bone marrow-derived very small embryonic-like stem cells differentiate into the hematopoietic lineage after coculture over OP9 stromal cells. Exp Hematol 39: 225-237, 2011.

31. Ratajczak M, Tarnowski M, Staniszewska M, Sroczynski T and Banach B: Mechanisms of cancer metastasis: Involvement of cancer stem cells? Minerva Med 101: 179-191, 2010.

32. Ratajczak J, Kucia M, Mierzejewska K, Marlicz W, Pietrzkowski Z, Wojakowski W, Greco NJ, Tendera M and Ratajczak MZ: Paracrine proangiopoietic effects of human umbilical cord blood-derived purified $\mathrm{CD}_{133^{+}}$cells - implications for stem cell therapies in regenerative medicine. Stem Cells Dev 22: 422-430, 2013.

33. Wu W, Kim CH, Liu R, Kucia M, Marlicz W, Greco N, Ratajczak J, Laughlin MJ and Ratajczak MZ: The bone marrow-expressed antimicrobial cationic peptide LL-37 enhances the responsiveness of hematopoietic stem progenitor cells to an SDF-1 gradient and accelerates their engraftment after transplantation. Leukemia 26: 736-745, 2012.

34. Ratajczak MZ and Ratajczak J: Horizontal transfer of RNA and proteins between cells by extracellular microvesicles: 14 years later. Clin Transl Med 5: 7, 2016.

35. Krasnova Y, Putz EM, Smyth MJ and Souza-FoncescaGuimaraes F: Bench to bedside: NK cells and control of metastasis. Clin Immunol: Oct 22, 2015 (Epub ahead of print). doi: $10.1016 /$ j.clim.2015.10.001.
36. Bhartiya D and Patel H: Very small embryonic-like stem cells are involved in pancreatic regeneration and their dysfunction with age may lead to diabetes and cancer. Stem Cell Res Ther 6: 96, 2015.

37. Morgan BP and Harris CL: Complement, a target for therapy in inflammatory and degenerative diseases. Nat Rev Drug Discov 14: 857-877, 2015.

38. Rutkowski MJ, Sughrue ME, Kane AJ, Ahn BJ, Fang S and Parsa AT: The complement cascade as a mediator of tissue growth and regeneration. Inflamm Res 59: 897-905, 2010.

39. Lee HM, Wu W, Wysoczynski M, Liu R, Zuba-Surma EK, Kucia M, Ratajczak J, Ratajczak MZ and Ratajczak MZ: Impaired mobilization of hematopoietic stem/progenitor cells in C5-deficient mice supports the pivotal involvement of innate immunity in this process and reveals novel promobilization effects of granulocytes. Leukemia 23: 2052-2062, 2009.

40. Amara U, Flierl MA, Rittirsch D, Klos A, Chen H, Acker B, Brückner UB, Nilsson B, Gebhard F, Lambris JD, et al: Molecular intercommunication between the complement and coagulation systems. J Immunol 185: 5628-5636, 2010.

41. Schneider G, Sellers ZP and Ratajczak MZ: Induction of a tumor-metastasis-receptive microenvironment as an unwanted side effect after radio/chemotherapy and in vitro and in vivo assays to study this phenomenon. Methods Mol Biol: Apr 1, 2016 (Epub ahead of print) doi: 10.1007/7651_2016_323.

42. Shaikh A, Bhartiya D, Kapoor S and Nimkar H: Delineating the effects of 5-fluorouracil and follicle-stimulating hormone on mouse bone marrow stem/progenitor cells. Stem Cell Res Ther 7: 59, 2016.

43. Bhartiya D. Intricacies of pluripotency. J Stem Cells Regen Med 11: 2-6, 2015

44. Marlicz W, Zuba-Surma E, Kucia M, Blogowski W, Starzynska T and Ratajczak MZ: Various types of stem cells, including a population of very small embryonic-like stem cells, are mobilized into peripheral blood in patients with Crohn's disease. Inflamm Bowel Dis 18: 1711-1722, 2012.

45. Piao C, Cai L, Qiu S, Jia L, Song W and Du J: Complement 5 a enhances hepatic metastases of colon cancer via monocyte chemoattractant protein-1-mediated inflammatory cell infiltration. J Biol Chem 290: 10667-10676, 2015.

46. Białek A, Pertkiewicz J, Karpińska K, Marlicz W, Bielicki D and Starzyńska T: Treatment of large colorectal neoplasms by endoscopic submucosal dissection: A European single-center study. Eur J Gastroenterol Hepatol 26: 607-615, 2014

47. Vaccaro V, Sperduti I, Vari S, Bria E, Melisi D, Garufi C, Nuzzo C, Scarpa A, Tortora G, Cognetti F, et al: Metastatic pancreatic cancer: Is there a light at the end of the tunnel? World J Gastroenterol 21: 4788-4801, 2015.

48. Ghosn M, Tabchi S, Kourie HR and Tehfe M: Metastatic gastric cancer treatment: Second line and beyond. World J Gastroenterol 22: 3069-3077, 2016. 